\title{
ЗАХВОРЮВАННЯ СИСТЕМИ КРОВІ ТА ВАГІТНІСТЬ
}

\section{ТРОМБОЦИТОПЕНІЯ}

Тромбоцитопенія - це зниження вмісту тромбоцитів у периферичній крові, тобто їх кількість $€$ меншою ніж 150 000/мл. Тромбоцитопенія може бути зумовлена підвищеним руйнуванням (що відбувається найчастіше), інтенсивним використанням або недостатнім утворенням тромбоцитів.

У залежності від кількості тромбоцитів в 1 мл крові тромбоцитопенії класифрікують за ступенем тяжкості:

легкого ступеня - 100 000-150 000 тромбоцитів/мл;

середнього ступеня тяжкості - 50 000-100 000 тромбоцитів /мл;

3 тяжкого ступеня < 50000 тромбоцитів/мл.

Виділяють спадкові (зустрічаються порівняно рідко) і набуті (більш часті) форми тромбоцитопеній.

Спадкові тромбоцитопенії спричинені дефектом у мембрані тромбоцитів, фрерментах; порушенням продукції тромбоцитів.

Набуті тромбоцитопенії в основному аутоімунні та імунні (гаптенові) з антитілами проти антигену тромбоцитів, мегакаріоцитів і загального попередника всіх ростків кровотворення. Прикладом аутоімунної тромбоцитопенії $\epsilon$ ідіопатична тромбоцитопенічна пурпура (хвороба Верльгофра).

Фізіологічна тромбоцитопенія виникає при фрізіологічній вагітності, проявляється лише при вагітності і має наступні характеристики:

3 зниження тромбоцитів відбувається в III триместрі;

3 причиною є гемодилюція та підвищена деструкція тромбоцитів;

н нормалізується через 24-72 год після пологів;

не потребує медикаментозної корекції.

У таблиці 1 наведено причини виникнення тромбоцитопеній при вагітності.
Ідіопатична тромбоцитопенічна пурпура

Ідіопатична тромбоцитопенічна пурпура (ITП), або хвороба Верльгофа - набута аутоімунна тромбоцитопенія, що характеризується посиленим руйнуванням тромбоцитів під дією антитромбоцитарних антитіл. Спостерігається з частотою 1-2 випадки на 1000 пацієнтів. Патофрізіологія ії добре зрозуміла, в той час як причина залишається невідомою. Лімфоцити виробляють антитіла до тромбоцитів - глікопротеїни, що деструктивно діють на поверхню тромбоцитів. Тромбоцитарні імуноглобуліни класу G (lgG) утилізуються макрофрагами селезінки.

Механізм аутоімунного процесу при ITП представлений на рисунку 1.

Захворювання зазвичай починається задовго до вагітності і характеризується:

क періодичними носовими кровотечами, кровоточивістю ясен та масивними менструальними кровотечами;

5 появою на шкірі і слизових оболонках петехіального висипу;

наявністю невеликих синців без причини або які виникли після легкого натискання (накладання манжетки тонометра, пальпації органів тощо);

ТАБЛИЦЯ 1

\begin{tabular}{|c|c|}
\hline Причини, специфічні для вагітності & Причини, неспецифічні для вагітності \\
\hline $\begin{array}{c}\text { Гестаційна тромбоцитопенія } \\
\text { Прееклампсія } \\
\text { HELLP-синдром (гемоліз, підвищення } \\
\text { активності печінкових ферментів і } \\
\text { тромбоцитопенія) } \\
\text { Гостра жирова дистрофія печінки } \\
\text { Дисемінована судинна коагулопатія }\end{array}$ & $\begin{array}{c}\text { Підвищена деструкція тромбоцитів: } \\
\text { - ідіопатична тромбоцитопенічна пурпура } \\
\text { - мікроангіопатії } \\
\text { - системний червоний вовчак } \\
\text { - антифоосфоліпідний синдром } \\
\text { Зумовлена медикаментами } \\
\text { Вірусна інфекція: ВІЛ, вірус гепатиту типу C, вірус } \\
\text { Епштейна - Барр, цитомегаловірус } \\
\text { Гіперспленізм } \\
\text { Знижена продукція тромбоцитів: } \\
\text { - захворювання кісткового мозку } \\
\text { - дефіцит харчування } \\
\text { - захворювання печінки }\end{array}$ \\
\hline
\end{tabular}




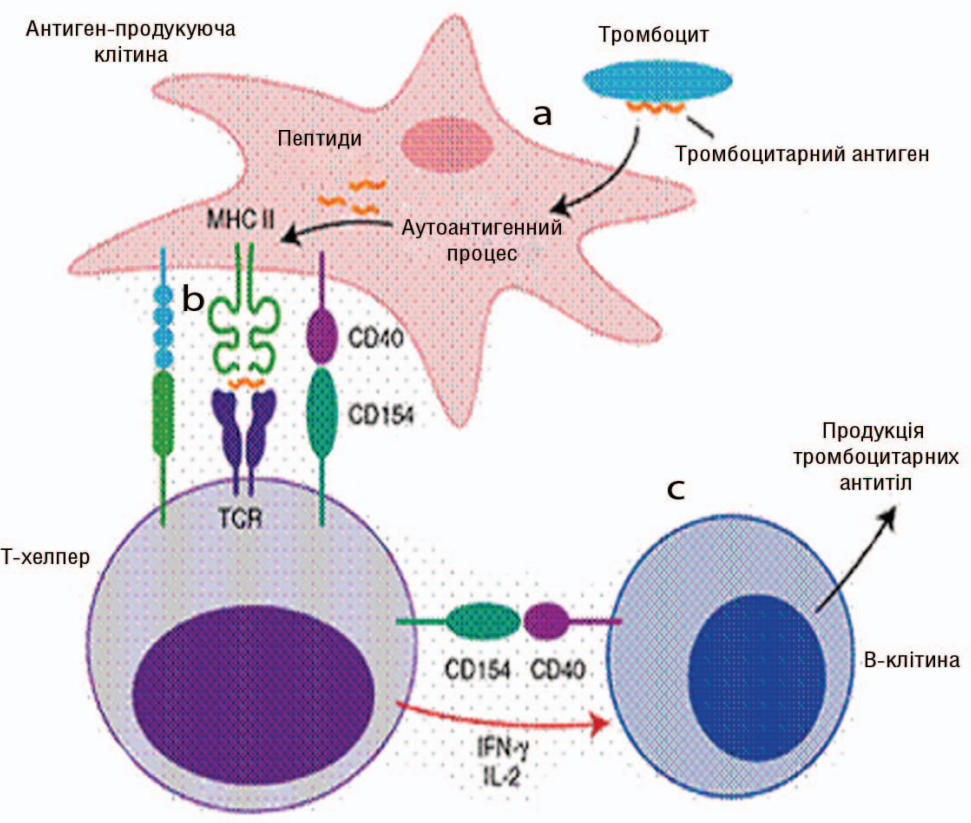

РИС. 1.

MEХАНІЗМ АУТОІМУННОГО ПРОЦЕСУ ПРИ ІТП

а - тромбоцити деградуються антиген-продукуючими клітинами (АРC);

b - APC діють в асоціації з основним комплексом гістосумісності класу II (MHC II) на Т-хелпери, що продукують інтерлейкін 2-го типу (IL-2) та $\gamma$-інтерферон (IFN- $\gamma$ );

c - Т-хелпери активують аутореактивні В-клітини та диференціюють їх в клітини, що продукують аутоантитіла розташовані екстравазати;

5 печінка та селезінка не збільшені. зменшення симптоматики захворювання. на шкірі кінцівок, особливо нижніх, на животі, грудях, рідше на інших ділянках тіла

Вагітність часто зумовлює загострення хвороби, особливо в І-ІІ триместрі. Рецидив її у такому разі може бути пов'язаний із продукцією антитромбоцитарних антитіл селезінкою плода. Разом із тим під час вагітності можливе

Ускладнення під час вагітності та пологів виникають переважно у жінок із загостренням хронічного рецидивуючого перебігу захворювання. Перебіг вагітності і пологів залежить від характеру лікування, що передувало вагітності. Спленектомія, виконана до вагітності, нерідко знижує частоту і тяжкість ускладнень для матері. У кожної шостої жінки з ІТП вагітність супроводжується загрозою переривання, у кожної восьмої - розвитком пізнього гестозу.

Захворювання матері впливає на стан плода і новонародженого. Тромбоцитопенія $є$ найбільш частим ускладненням періоду новонародженості і спостерігається у 60-80\% дітей. Тромбоцитопенія $€$ причиною розвитку геморагічного синдрому i

ТАБЛИЦЯ 2

\begin{tabular}{|c|c|c|}
\hline Параметри & Гестаційна пурпура & ITח \\
\hline Механізм розвитку & $\begin{array}{c}\text { Гемодилюція, прискорений обіг } \\
\text { тромбоцитів. Трепінг (потовщення } \\
\text { контурів) або деструкція } \\
\text { тромбоцитів у плаценті }\end{array}$ & Аутоімунний \\
\hline Частота & $\begin{array}{c}\text { 5-8\% усіх вагітностей; } \\
\text { 75\% усіх тромбоцитопеній, } \\
\text { асоційованих з вагітністю }\end{array}$ & $\begin{array}{c}\text { 0,1\% усіх вагітностей; } \\
\text { 5\% тромбоцитопеній, } \\
\text { асоційованих з вагітністю }\end{array}$ \\
\hline Ризик кровотечі у матері & Не підвищений & Підвищений \\
\hline Ризик кровотечі у плода & Не підвищений & Підвищений \\
\hline Клінічні прояви & У III триместрі & У І-ІІ триместрі \\
\hline
\end{tabular}

ТАБЛИЦЯ 2.

ДИФЕРЕНЦІАЛЬНА ДІАГНОСТИКА ГЕСТАЦІЙНОЇ ПУРПУРИ ТА ІТП внутрішньочерепних крововиливів, що призводять до смерті немовлят. Також достатньо часто зустрічаються гіпотрофрія та ассріксія.

\section{Лабораторні дослідження}

Діагноз ITП у вагітних підтверджують результати лабораторних досліджень:

у мазку крові відмічається:

- тромбоцитопенія (10-40 тромбоцитів × 10\%/л);

- якщо аналізу передувала крововтрата - зниження рівня гемоглобіну, зменшення кількості еритроцитів, гіпохромія еритроцитів;

5 плазмові фрактори згортання крові не змінені;

3більшена тривалість кровотечі;

уповільнена ретракція кров'яного згортка;

5 в пунктаті кісткового мозку збільшена кількість мегакаріоцитів.

\section{Диференціальна діагностика}

Диференціальна діагностика гестаційної та ITП наведена у таблиці 2.

\section{Лікування}

Пацієнтки з ІТП можуть почуватися гірше від лікувального режиму, аніж від самої хвороби. Метою терапії $є$ збільшення кількості тромбоцитів до безпечного рівня (більше ніж 20 000-30 000/мл) з якомога меншим фрармакотерапевтичним навантаженням на організм (рис. 2).

Зауважимо, що безпечний рівень тромбоцитів не завжди відповідає їх загальному нормальному рівню. Кількість материнських тромбоцитів менше 20 000-30 000/мл є показанням для початку терапії глюкокортикоїдами (преднізолон у дозі 1-2 мг/кг/доб). Як тільки кількість тромбоцитів сягатиме безпечного рівня, лікування слід припинити. Протягом 3 тиж піддаються лікуванню 70-90\% пацієнтів.

Ремісія може вважатися повною, якщо одночасно з припиненням кровотечі відмічається збільшення кількості тромбоцитів до безпечного рівня; частковою, якщо при її припиненні рівень тромбоцитопенії суттєво не змінюється.

Після досягнення ремісії добову дозу преднізолону можна знижувати швидко - по 5 мг в день - до 30-40 мг/доб. Після цього дозу препарату знижують поступово - по 2,5-5 мг/тиж.

Для пацієнток, які не піддаються лікуванню стероїдами, рекомендоване внутрішньовенне введення імуноглобуліну. Механізм дії $\gamma$-глобуліну полягає в пролонгації періоду очищення тромбоцитарних IgG материнською ретикуло-ендотеліальною системою.

Існують наступні режими введення препарату:

5 400 мг/кг/доб протягом 5 днів на тиждень упродовж 3 тиж;

\section{1 г/кг/доб протягом 1 тиж.}

Накопичений досвід застосування $\gamma$-глобуліну свідчить про те, що завдяки його введенню досягається позитивний результат вже за 
6-72 год, відбувається тимчасове підвищення рівня тромбоцитів майже у 50\% лікованих, а терапевтичний ефект зберігається протягом 2-3 тиж. Рівень ефективності $\gamma$-глобуліну сягає $80 \%$, однак вартість терапії значно перевищує лікування кортикостероїдами.

Показання для введення імуноглобулінів:

(5) число тромбоцитів у III триместрі < 10 000/мл;

к кількість тромбоцитів < 30 000/мл і наявність проявів геморагічного синдрому;

5 число тромбоцитів < 30 000/мл та вірогідність оперативного абдомінального розродження.

Терапія імуноглобуліном менш ефективна у жінок, які перенесли спленектомію.

Спленектомію при вагітності призначають рідко.

Імуносупресивна терапія $€$ суперечливою і сумнівною і зазвичай теж не застосовується, оскільки є потенційно шкідливою для плода в стадії розвитку.

Переливання тромбоконцентрату. Проводиться при масивній крововтраті за життєвими показаннями. При цьому необхідно пам'ятати про аутоімунний характер захворювання.

\section{Тактика ведення вагітності}

При ІТП в стадії стійкої клініко-гематологічної ремісії рекомендується вичікувальна тактика ведення вагітності. Слід проводити планові запобіжні заходи щодо травм і інфекційних захворювань. Варто намагатися уникати застосування фрармпрепаратів, що знижують функцію тромбоцитів (дигітоксин, діуретичні, антибактеріальні засоби). Пацієнткам із хворобою Верльгофа протипоказане лікування антиагрегантами, оскільки вони пригнічують фрункцію тромбоцитів, і антикоагулянтами у зв'язку з високим ризиком розвитку кровотечі.

Протипоказанням для виношування вагітності $\epsilon$ часті рецидиви захворювання. У даного контингенту жінок краще запобігти вагітності, аніж перервати їі. Це може бути більш небезпечним, ніж пролонгування вагітності.

Розродження жінок з ІТП здійснюється виключно в лікувальних закладах III рівня акредитації, при доношеній вагітності (після 37 тиж), консервативно, природними пологовими шляхами. Досить часто пологи у таких пацієнток ускладнюються слабкістю пологової діяльності і кровотечами в третьому і ранньому післяпологовому періодах. Саме на ці моменти повинні бути спрямовані планові профрілактичні заходи. Абдомінальне оперативне розродження у жінок з ІТП проводиться виключно за акушерськими показаннями.

У матері з ITП підвищений ризик кровотечі залежить від рівня тромбоцитів:

< 20 000/мл-існує ризик спонтанної кровотечі;

s 50 000/мл - можливе виконання операції кесарева розтину;

> 70 000/мл - можливе проведення епідуральної анестезії.
Необхідно пам'ятати про ризик розвитку фетальної тромбоцитопенії (внаслідок трансплацентарного пасажу материнських $\mathrm{lgG}$ ). У $10-20 \%$ новонароджених число тромбоцитів становить < 50 000/мл, а у 25-50\% таких дітей можливий розвиток кровотечі, в т.ч. внутрішньошлуночкової.

\section{Контрацепція}

У жінок із хворобою Верльгофра перевагу слід надавати гормональній контрацепції з використанням комбінованих монофазних препаратів.

\section{Вторинні тромбоцитопенії}

Вторинні тромбоцитопенії є наслідком впливу на організм різних чинників зовнішнього i внутрішнього середовища, при яких тромбоцитопенія як симптом не є провідною, а входить до симптомокомплексу панцитопенії.

До таких фракторів належать:

क фізичні: радіація;

з хімічні: лікарські засоби, солі важких металів, етанол, уремія;

біологічні: пухлини;

5) зменшення тромбоцитопоезу: остеолімфіброз;

вроджена гіпоплазія мегакаріоцитів;

3 авітаміноз: дефіцит вітаміну $\mathrm{B}_{12}$, фолієвої кислоти.

\section{Тромбоцитопенія, зумовлена дією лікарських} засобів

Тромбоцитопенія, що виникла внаслідок застосування препаратів, діагностується на підставі збігу в часі їх прийому та розвитку тромбоцитопенії.

Лікарські засоби можуть викликати тромбоцитопенію різними шляхами. Так, цитостатики здатні пригнічувати тромбоцитопоез у кістковому мозку. Хінідин, сульфаніламіди, саліцилати, дипіридамол, препарати золота, цефалотин, триметоприл, $\alpha$-метилдопа та інші

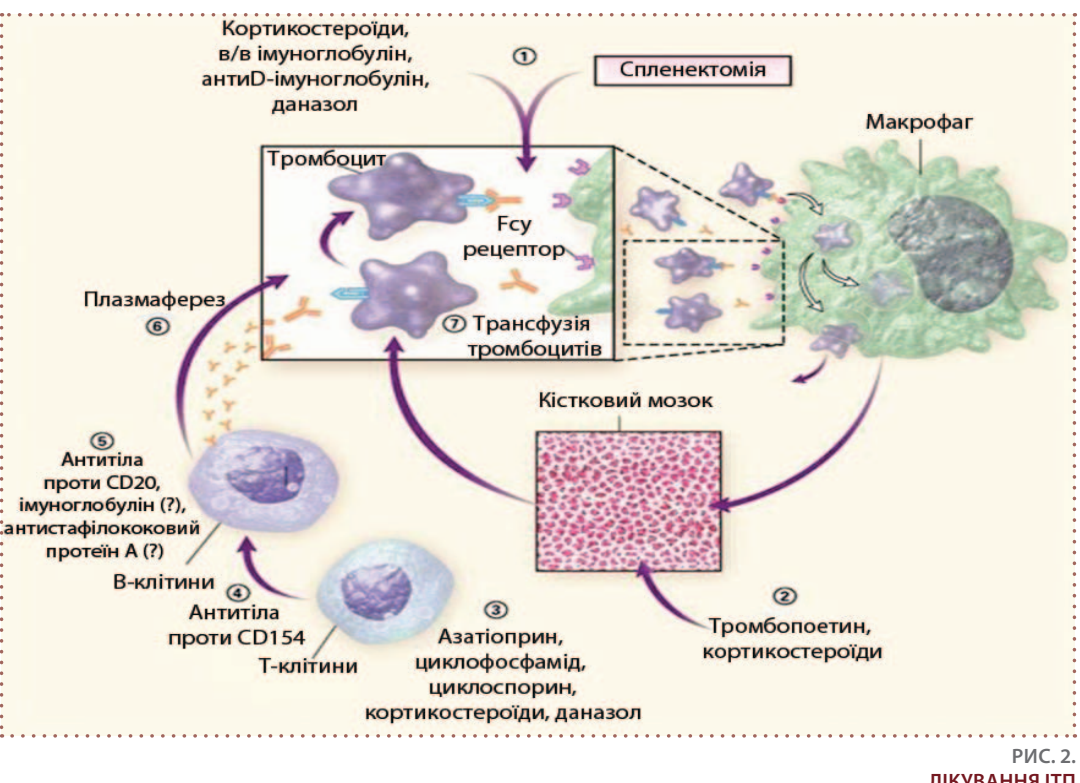

Абдомінальне оперативне розродження у жінок з ІTП проводиться виключно за акушерськими показаннями

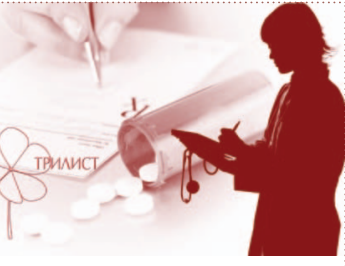

При лікуванні хворих з тромбоцитопенією невизначеного генезу необхідно відмовитися від застосування будь-яких лікарських засобів, окрім життєво необхідних 
можуть активувати імунні механізми. Вони провокують тромбоцитопенію, осідаючи на тромбоцитах і стимулюючи утворення антитіл до цього комплексу. Деякі лікарські засоби утворюють комплекси з білком плазми, який потім приєднується до мембрани тромбоцитів і викликає утворення антитіл вже до цього складного комплексу. Інші препарати зумовлюють деструкцію самих тромбоцитів і тим самим сприяють утворенню антитіл безпосередньо до них.

Зазвичай тромбоцитопенія зникає через декілька діб після припинення застосування препарату, що її спричинив. Інколи вона триває протягом декількох місяців, оскільки деякі речовини (препарати золота) повільно виводяться 3 організму. Зауважимо, що при лікуванні пацієнток із тромбоцитопенією невизначеного генезу необхідно відмовитися від застосування будь-яких лікарських засобів, окрім життєво необхідних. Використання преднізолону дозою 1 мг/кг/доб може зменшити тривалість тромбоцитопенії. У разі тромбоцитопенії, що виникла внаслідок застосування лікарських засобів, трансфузія тромбоцитарної маси зазвичай $є$ неефективною. Ії̈ застосування можливе при вираженому геморагічному синдромі.

\section{Тромбоцитопенія, зумовлена трансфузіями}

Посттранссрузійна пурпура належить до імунних тромбоцитопеній, що рідко зустрічаються. Вона виникає у $\mathrm{P} \alpha \mathrm{A} 1$ негативних жінок, які народжували багаторазово (імунізованих під час вагітності). Прояви захворювання спостерігаються через 7 діб після переливання крові, мають тяжкий перебіг і можуть супроводжуватися внутрішньочерепними крововиливами. При такому стані застосовують такі лікувальні заходи:

плазмозаміщення при плазмофререзі;

призначення імуноглобуліну дозою 400 мг/кг/доб внутрішньовенно упродовж 5 діб.

Слід звернути особливу увагу на те, що переливання тромбоцитарної маси протипоказане; ефективність глюкокортикоїдів - сумнівна.

\section{Тромбоцитопенія при HELLP-синдромі}

Тромбоцитопенія при HELLP-синдромі $€$ найбільш поширеною причиною виникнення материнської тромбоцитопенії. Зустрічається майже у $10 \%$ жінок з тяжкою прееклампсією.

Синдром HELLP зумовлюється збільшеним циклом життя тромбоцитів, пов'язаним як з ендотеліальними порушеннями, так і з коагулопатіями. Прояви симптомів HELLP-синдрому (гемоліз, підвищення рівня трансаміназ і тромбоцитопенія) припиняються на 5-ту добу після пологів.

При проведенні диференційної діагностики з хворобою Мошковіц (тромботичною тромбоцитопенічною пурпурою) основним критерієм є визначення рівня антитромбіну III, який знижується при прееклампсії, а при тромбоцитопенії, тромбоцитопенічній пурпурі залишається сталим.

\section{Тромбоцитопенія, зумовлена ВІЛ-інфрекцією}

Тромбоцитопенія може бути першим проявом ВІЛінфекції. Частіше спостерігається ізольована тромбоцитопенія, яка за своїми клінічними проявами нагадує ITП. Через наявність імунодефіциту застосування глюкокортикоїдів і імуносупресивної терапії як лікувальних заходів обмежене.

\section{ХВОРОБА ВІЛЛЕБРАНДА}

Хвороба Віллебранда належить до спадкової патології гемостазу, передається за аутосомно-домінантним типом і пов'язана з патологією плазменної ланки гемостазу - дефріцитом фрактора Віллебранда. Серед вагітних зустрічається в 1 випадку на 10 000-20 000 пологів.

\section{Класифікація}

Традиційним є поділ хвороби на три типи, які різняться особливостями наслідування, кількісними і якісними дефектами фррагментів VIII фрактора згортання крові і за ступенем вираженості коагуляційних порушень:

І І тип (80\% випадків) - класичний;

(II тип (II a та II b) - домінантний;

s III тип - рецесивний.

У $80 \%$ випадків зустрічається I тип захворювання, який наслідується за домінантним типом, характеризується кількісним дефектом активності фрактора Віллебранда, пов'язаним з коагулянтною активністю VIII фрактора згортання крові.

\section{Етіологія і патогенез}

VIII фрактор згортання крові складається 3 двох компонентів: низькомолекулярного, який забезпечує коагулянтну, антигемофільну активність (VIII-K фрактор), і високомолекулярного, який впливає на первинний гемостаз (фактор Віллебранда, VIII-ФВ). Фактор Віллебранда синтезується в ендотелії судин і в мегакарціотих. Його участь у гемостазі полягає в тому, що при взаємодії фактора Віллебранда, який знаходиться в плазмі, і глікопротеїну І, який знаходиться в мембрані тромбоцита, відбувається адгезія тромбоцитів до субендотелію судин.

\section{Клініка, особливості перебігу хвороби у вагітних, ускладнення вагітності}

Проявами захворювання є поява петехіальних або петехіально-плямистих висипів на шкірі, носі; маткові кровотечі (ювенільна кровотеча може бути дебютом захворювання). Можливі тривалі значні кровотечі (шлунковокишкові, маткові до 15-25 днів, крововиливи у великі суглоби, гематурія, внутрішньочерепні крововиливи, кровотеча після екстракції зуба або іншого хірургічного втручання).

Під час вагітності суттєво змінюється перебіг хвороби. 3 кінця II-початку III триместру вагітності коагулянтна активність VIII фрактора зростає на 250-350\%, значною мірою за рахунок фрактора Віллебранда, який жінка отримує від плода. Вагітність супроводжується ремісією зі значним зменшенням гемостазіологічних ознак.

Підвищення рівня гормонів під час вагітності має протективну дію, оскільки стимулює зростання рівня VIII фрактора згортання крові в перші 2 міс після пологів. У роділь, які не годують грудьми, зниження рівня VIII фрактора призводить до розвитку маткової кровотечі через 7-14 днів після пологів.

Деякі періоди вагітності $€$ особливо небезпечними: до 12 тиж (можуть спостерігатися мимовільні викидні) і 6-13-та доба післяпологового періоду. У третини жінок вагітність ускладнюється загрозою переривання, прееклампсією різного ступеня тяжкості. Найбільш тяжким ускладненням $€$ передчасне відшарування нормально розташованої плаценти з масивною кровотечею. 


\section{Діагностика}

3 метою діагностики хвороби застосовують спеціальне гемостазіологічне дослідження, яке виявляє класичні ознаки:

подовження часу кровотечі понад 15 хв., яке визначається методом Ivy, а не методом Duce;

5 зниження або відсутність активності фактора Віллебранда;

3 зниження вмісту антигену, пов'язаного 3 VIII фрактором;

з зниження коагулянтної активності VIII фрактора, про що можна судити за подовженням активованого часткового тромбопластинового часу або активованого часу рекальцифікації;

для визначення активності фрактора Віллебранда оцінюють рістоцетин-кофракторну активність - один з найбільш точних методів діагностики хвороби Віллебранда; він полягає у виявленні різкого зниження або повної відсутності рістоміцин-агрегації тромбоцитів, що характеризують активність фрактора VIII-ФВ.

\section{Лікування}

Терапія включає внутрішньовенне введення кріопреципітату, який містить фрактор Віллебранда, VIII фрактор, фрібріноген та інші фрактори згортання крові. 3 початку пологів призначають профрілактичне введення кріопреципітату за схемою: 0,24 дози/кг (15-25 доз), потім 0,12 дози/кг (7-12 доз) кожні 12 год упродовж 7 діб. Після пологів призначають десмопресин, який сприяє вивільненню фактора Віллебранда з ендотеліальних клітин, що запобігає розвитку кровотечі.

Хвороба Віллебранда є прямим показанням для вакцинації проти гепатиту $B$, оскільки пацієнткам часто переливають компоненти крові.

\section{ГЕМОБЛАСТОЗИ}

Лейкози - пухлини кровотворної тканини, що уражають кістковий мозок. Захворюваність на лейкози не перевищує 0,9-1,2 випадку на 100 тис. жінок на рік. Лейкози класифрікують за варіантом перебігу (гострі та хронічні) і за цитоморфотипом. Діагноз встановлюється за результатами дослідження мазків крові, пунктату кісткового мозку, визначення поверхневих антигенів та цитохімічних властивостей клітин.

\section{Гострі лейкози}

Гострий лімфобластний лейкоз частіше зустрічається в дитинстві, його перебіг в дитячому віці вважається більш сприятливим. Вагітність настає лише у випадках, коли в дитинстві вдалося досягти ремісії захворювання.

Гострий нелімфобластний лейкоз частіше розвивається у дорослих. Тривалої ремісії досягають у 10-20\% хворих, фрертильність значно знижена, вагітність настає рідко.

Основні питання взаємовпливу лейкозу та вагітності наведено у таблиці 3.

ТАБЛИЦЯ 3

Чи впливає гестаційний процес на перебіг лейкозу?

Чи впливає лейкоз на перебіг вагітності?

Чи впливає лікування лейкозу на подальшу фертильність?

Чи впливає лікування лейкозу на перебіг вагітності?
Гестаційний процес не впливає на перебіг лейкозу. Імунологічна толерантність розвивається лише до тканин плода, а клітинний імунітет не порушується

При лейкозі існує ризик самовільного викидня, передчасних пологів, затримки внутрішньоутробного розвитку. Результат вагітності залежить від ефективності лікування. Лейкозна інфрільтрація плаценти та тканин плода спостерігається досить рідко

При нелікованому лейкозі прогноз для вагітної вкрай несприятливий, тому під час вагітності призначається хіміотерапія. Існує відносна ймовірність вад розвитку, висока ймовірність затримки внутрішньоутробного розвитку. Віддалені наслідки впливу лікування (радіо- та хіміотерапії) на фрізичний та інтелектуальний розвиток дітей не вивчались

Фертильність на фоні рецидивів лейкозу знижується. Якщо ремісії досягнуто до початку статевого розвитку, здатність до народження дітей зберігається

\section{Тактика ведення вагітності}

Якщо лейкоз діагностовано в I триместрі вагітності, ії̈ виношування протипоказане. Жінці, яка відмовилася від переривання вагітності, необхідно призначити хіміотерапію. При виявленні захворювання в III триместрі вагітності проведення хіміотерапії можна відкласти на післяпологовий період. Для контрацепції використовуються пероральні контрацептиви. При пригніченні овуляції застосування такої контрацепції знижує ризик менорагій.

\section{Хронічні лейкози}

Хронічний лімфолейкоз зазвичай зустрічається у жінок після 50 років, тому у вагітних частіше виявляється хронічний мієлолейкоз. При бластних кризах призначають поліхіміотерапію. При цьому ведення вагітності таке ж саме, як і при гострому лейкозі. Існує високий ризик затримки внутрішньоутробного розвитку плода.

\section{Вагітність після трансплантації кісткового мозку}

У публікаціях останніх трьох років представлені дані стосовно 19412 пацієнтів з алогенною трансплантацією кісткового мозку (TKM) та 179590 - з аутологічною TKM (результати отримані з 199 європейських центрів TKM). Проведено аналіз 312 вагітностей у 113 пацієнток (у 74 випадках для трансплантації використовували алографт). Заслуговує на увагу висока частота виконання операції кесарева розтину у цієї групи пацієнток (42 проти 16\% в контрольній групі) та підвищена розповсюдженість передчасних пологів (20 проти 6\% відповідно). Рекомендовано спостерігати за перебігом вагітності у таких хворих та проводити розродження у лікувальних закладах вищого рівня надання перинатальної допомоги. 